\title{
Does the efficacy of different doses of Botulinum neurotoxin in chronic migraine change in terms of age and sex?
}

\author{
(D) Akçay Övünç Özön
}

Yuksek Ihtisas University, Liv Hospital, Clinic of Neurology, Ankara, Turkey

Date submitted:

19.12.2019

Date accepted:

09.02.2020

Online publication date: 15.03.2020

\section{Corresponding Author:}

Akçay Övünç Özön MD, Yüksek

Intisas University, Liv Hospital, Clinic

of Neurology, Ankara, Turkey

akcozon@gmail.com

ORCID:

orcid.org/0000-0003-3427-1207

Keywords: Chronic migraine, migraine, Botulinum toxin $\mathrm{A}$

\begin{abstract}
Aim: The aim of this study was to investigate the effectiveness of Botulinum toxin A (BoNTA) treatment at different doses according to age and sex.

Methods: In this study, 53 patients diagnosed as chronic migraine (CM) were evaluated. The patients were divided into four groups. Group $1 \mathrm{a}(\mathrm{n}=13)$ were elderly patients who received 5 $\mathrm{U}$ BoNTA. Group $1 \mathrm{~b}(\mathrm{n}=13)$ were elderly patients who received $2.5 \mathrm{U}$ BoNTA. Group 2a $(\mathrm{n}=14)$ were young patients who received $5 \mathrm{U}$ BoNTA. Group $2 b(n=13)$ were young patients who received 2.5 $\mathrm{U}$ BoNTA. In all patients, the number of headache days and the severity of pain were compared before and after the treatment.
\end{abstract}

Results: There was a statistically significant difference between the number of headache days and the severity of pain in group $1 \mathrm{a}$, group $1 \mathrm{~b}$, and group $2 \mathrm{a}$ at 3-month post-treatment $(p<0.05)$. In the comparison between the groups, there was a statistically significant decrease in pain intensity in group $1 \mathrm{~b}$ compared to group $2 \mathrm{~b}$ in which $2.5 \mathrm{U}$ BoNTA was applied $(\mathrm{p}<0.05)$.

Conclusion: In the treatment of CM, $5 \mathrm{U}$ BoNTA applications were found to be an effective treatment method in both young and old population. However, the efficacy of $2.5 \mathrm{U}$ of BoNTA treatment was seen to be superior in the elderly population compared to the younger population.

\section{Introduction}

Headaches constitute an important part of the burden of neurological diseases. Migraine is one of the most important causes of disability among these headaches. In communitybased studies, chronic migraine (CM) was found at different rates. Studies have shown that $\mathrm{CM}$ costs are three to four times higher than the cost of episodic migraine. Poor clinical status of $\mathrm{CM}$ has been cited as the reason for these high costs. Migraine has an impact both on direct health costs and indirectly on labor costs as it causes labor loss. Studies have shown that CM also has negative effects on school and family life (1).

Trigeminovascular system, which is comprising of sensory neurons arising from the trigeminal ganglion and the upper cervical dorsal roots, generates the migraine pathophysiology (2). Neurogenic inflammation is known to be most important parameter of migraine pain, and substance $P$, the calcitonin gene-associated peptide and neurokinin A are accepted to be vasoactive neuropeptides that released with stimulation of the trigeminal ganglion. In addition, neurogenic inflammation can lead to a sensitivity process. There is a continuous activation of the trigeminovascular system in patients with CM. Increased vasoactive neuropeptide levels in cerebrospinal fluid have been found to be associated with this condition $(3,4)$.

When the studies on the preventive treatment of $\mathrm{CM}$ are reviewed, there are important deficiencies regarding the study design. Because the study designs are heterogeneous, it is difficult to compare the results of similar studies and it leads to conflicting results in terms of treatment efficacy (5). CM is a headache that is difficult to treat. Analgesics, anti-epileptics, antidepressants, beta blockers, calcium channel blockers, greater occipital nerve blockade, Botulinum toxin applications and cognitive behavioral therapy are used in the treatment (6-9).

In recent years, OnabotulinumtoxinA (BoNT-A) injections to the muscles in the head and neck region have been used in the treatment of CM $(10,11)$. It has been understood that BoNTA is effective through different mechanisms. Due to its axonal 
transport feature, it affects anatomically different regions besides the area where it is injected. In addition, it has been determined that BoNTA regulates neurotransmitter release and makes changes in the expression of receptors and cytokines. Some randomized, placebo-controlled studies have reported that $\mathrm{CM}$ patients respond well to BoNTA injections to the muscles (in the head and neck region), which are effective in treatment $(10,11)$.

The aim of this study was to define the efficacy of different BoNTA dosing treatments in terms of age and gender in the treatment of $\mathrm{CM}$ patients.

\section{Methods}

All patients underwent the procedure after obtaining written informed consent. This study was approved by the LIV Hospital Local Ethics Committee (protocol no: 2019/002-008).

Patients older than 18 years of age who were diagnosed with $\mathrm{CM}$ in accordance with the diagnostic criteria (third edition of the International Classification of Headache Disorders) published by the International Headache Association were included in the study. CM patients with a history of headache for more than 6 months from onset and having a headache of 15 days or more per month were selected. In order to exclude secondary causes, the data of patients who underwent whole blood, routine biochemistry, thyroid function tests, vitamin B12, folic acid, ferritin levels and brain imaging methods were analyzed.

Patients that received any kind of preventive treatment for $\mathrm{CM}$ at the last 6 months were excluded from the study. Patients with a history of neuromuscular junction disease, those receiving aminoglycoside group antibiotics or curar-like pharmacological agents affecting neuromuscular functions, pregnant patients, those with a history of malignancy, those with cervical and cranial surgery history, those who received non-pharmacological treatment during BoNTA administration, those with major psychiatric disease history in the last 3 months before the study, those taking antipsychotics, antidepressants, antiepileptic drugs, and those with drug overuse headache were not included in the study.

Fifty-three patients [39 female, 14 male-26 (49.1\%) were in the geriatric age group and 27 (50.9\%) were in the adult age group] were analyzed retrospectively and were included in the study according to inclusion and exclusion criteria. Botox injections were applied by the same specialist (neurologist) to half of the patients in a single session for a total of 60 units, 5 units to each muscles and the other half of the patients in a single session for a total of 30 units, 2.5 units to each muscles (bilaterally to frontal muscles, temporal muscles, occipital muscles, semispinalis capitis, splenius capitis and trapezius muscles in the cervical region). The injections were performed at the myofascial trigger points, the dominant areas of pain in the pericranial muscles. Pain intensity in the headache diaries of all patients before and after the third month was recorded using Visual Analogue Scale (VAS).

\section{Statistical Analysis}

In the analysis of descriptive statistical data, mean \pm standard deviation, median, minimum, maximum values were used for continuous variables, and number and "\%" expressions were used for discrete data. The comparison of categorical data between the groups was made by the chi-square test. For the analysis of continuous data, firstly, normality was analyzed by the Kolmogorov-Smirnov test. Parametric tests were used for the analysis of the data that fit the normal distribution and nonparametric tests were used for the data not suitable for the normal distribution.

Student's t-test was used for dependent variables in student dependent groups and Student's t-test was used for independent variables in dependent groups. The differences between the groups were taken as 95\%. SPSS 22.0 software was used for statistical analysis.

\section{Results}

Of the $53 \mathrm{CM}$ patients included in the study, 26 (49.1\%) were in the geriatric age group and 27 (50.9\%) were in the adult age group. In the geriatric age group (group 1), half of the patients received $5 \mathrm{U}$ (group 1a) and the other half received $2.5 \mathrm{U}$ (group 1b) BoNTA treatment. In the adult age group (group 2), 14 patients (group $2 \mathrm{a}$ ) received $5 \mathrm{U}$ and 13 patients received $2.5 \mathrm{U}$ (group 2b) BoNTA treatment. The mean age of group 1 patients was 68.0 (65-73) years, while the mean age of group 2 patients was 37.0 (24-49) years. When the gender distribution was examined, a similar distribution was observed in both groups. $73.1 \%(n=19)$ of the patients in group 1 were female and $26.9 \%$ of the patients $(n=7)$ in group 1 were male; $74.1 \%(n=20)$ of the patients in group 2 were female and $25.9 \%$ of the patients $(n=7)$ in group 2 were male $(p>0.05)$. There was no statistically significant difference between the subgroups in terms of age and sex ( $p>0.05)$ (Table 1).

In group 1 , the median number of headache days before the treatment was $19.0(15-25)$ days but decreased to 12.5 (5$17)$ days after the treatment $(p<0.01)$, and the median values of VAS for pain severity was $80(p<0.05)(70-95)$ and decreased to $60(30-80)$ after the treatment $(p<0.01)$. These decreases were statistically significant in terms of both the number of headache days and the severity of pain. There was a statistically significant decrease in the number of headache days and VAS pain severity after the treatment in group 2 (Table 2).

In group 1 patients, the median value of headache days was decreased by 8 days [minimum-maximum (-1) and 15 days], and the median value of VAS pain was decreased by 35 (0$55)$ points. When the treatment efficacy rates were compared to pre-treatment, the mean number of headache days after the 
treatment was $38.5 \%$ in group 1 and $41.3 \%$ in group 2 . The decrease in VAS pain intensity was $38.1 \%$ in group 1 and $37.4 \%$ in group 2. The mean number of headache days receiving 2.5 $U$ treatment was $37.5 \%$ in group 1, $20.7 \%$ in group 2, while the decrease in VAS pain severity was $38.5 \%$ in group 1 and $3.5 \%$ in group 2.

Before and after the treatment, there was a statistically significant decrease in the number of headache days in both group 1 and group 2 patients with both $2.5 \mathrm{U}$ and $5 \mathrm{U}$ BoNTA treatment $(p<0.01)$. Reduction in VAS pain intensity was statistically significant in both treatment doses in group 1 patients $(p<0.01)$. The decrease in VAS pain intensity before and after the treatment was not statistically significant in group 2 patients who received only $2.5 \cup$ treatment $(p=0.27)$ (Table 3).

There was no statistically significant difference in the number of headache days before and after the treatment in both group 1 and group 2 patients who received BoNTA treatment. There was no statistically significant difference between the groups in terms of the number of headache days and the severity of VAS pain before the treatment in the groups that received $2.5 \mathrm{U}$ treatment. There was a statistically significant decrease in the number of headache days and VAS pain score after the treatment in group 1 patients compared to group 2 patients $(p=0.01$ and $p<0.01$, respectively) (Table 4 ).

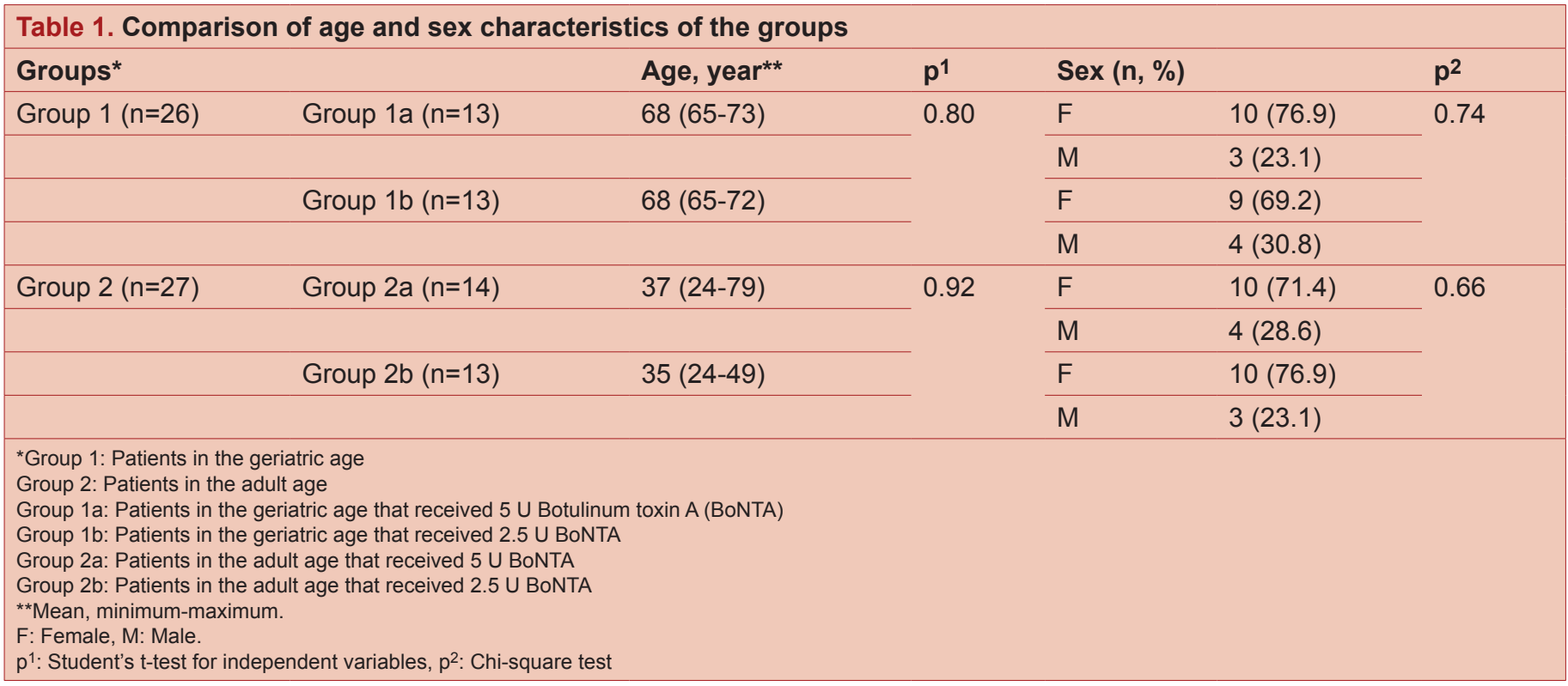

\begin{tabular}{|c|c|c|c|c|}
\hline Groups & & $\begin{array}{l}\text { Headache days before } \\
\text { treatment }\end{array}$ & $\begin{array}{l}\text { Headache days after } \\
\text { treatment }\end{array}$ & $\mathbf{p}^{* *}$ \\
\hline \multirow[t]{3}{*}{ Group $1(n=26)$} & Mean $\pm S D^{*}$ & $19.6 \pm 3.0$ & $11.9 \pm 3.5$ & \\
\hline & Mean & 19.0 & 12.5 & \\
\hline & Min.-max. & $15-25$ & $5-17$ & $<0.01$ \\
\hline \multirow{3}{*}{ Group 2 (n=27) } & Median & 20.0 & 13.0 & \\
\hline & Min.-max. & $16-25$ & $6-21$ & \\
\hline & & VAS before treatment & VAS after treatment & \\
\hline \multirow[t]{2}{*}{ Group $1(n=26)$} & Mean \pm SD & $79.6 \pm 7.4$ & $48.6 \pm 13.3$ & \\
\hline & Mean & 80.0 & 45.0 & \\
\hline Group $2(n=27)$ & Min.-max. & $70-95$ & $30-90$ & \\
\hline \multicolumn{5}{|c|}{$\begin{array}{l}{ }^{*} \text { Mean } \pm \text { SD: Mean } \pm \text { standard deviation, Min.-max.: Minimum-maximum. } \\
{ }^{*} \text { Student's t-test for dependent variables. } \\
\text { VAS: Visual Analogue Scale }\end{array}$} \\
\hline
\end{tabular}




\begin{tabular}{|c|c|c|c|c|c|c|c|}
\hline Age group & $\begin{array}{l}\text { Treatment } \\
\text { group }\end{array}$ & & $\begin{array}{l}\text { Headache } \\
\text { days before } \\
\text { treatment }\end{array}$ & $\begin{array}{l}\text { Headache days } \\
\text { after treatment }\end{array}$ & $\begin{array}{l}\text { Difference } \\
\text { in headache } \\
\text { days }\end{array}$ & $\begin{array}{l}\text { Decrease ratio } \\
\text { in headache } \\
\text { days }\end{array}$ & $\mathbf{p}^{* * *}$ \\
\hline \multirow[t]{6}{*}{ Group 1* } & \multirow{3}{*}{$\begin{array}{l}\text { Group 1a } \\
(n=13)\end{array}$} & Mean $\pm S D^{* *}$ & $19.5 \pm 3.0$ & $11.7 \pm 3.7$ & $7.8 \pm 4.8$ & \multirow[t]{3}{*}{38.5} & \multirow[t]{3}{*}{$<0.01$} \\
\hline & & Mean & 19.0 & 12.0 & 8.0 & & \\
\hline & & Min.-max. & $15-25$ & $5-17$ & $(-1)-15$ & & \\
\hline & \multirow{3}{*}{$\begin{array}{l}\text { Group 1b } \\
(n=13)\end{array}$} & Mean \pm SD & $19.6 \pm 3.1$ & $12.1 \pm 3.5$ & $7.5 \pm 4.1$ & \multirow[t]{3}{*}{37.5} & \multirow[t]{3}{*}{$<0.01$} \\
\hline & & Mean & 19.0 & 13.0 & 9.0 & & \\
\hline & & Min.-max. & $15-24$ & $5-17$ & $(-1)-12$ & & \\
\hline \multirow[t]{7}{*}{ Group 2} & \multirow{3}{*}{$\begin{array}{l}\text { Group 2a } \\
(n=14)\end{array}$} & Mean \pm SD & $20.1 \pm 2.3$ & $11.8 \pm 4.1$ & $8.3 \pm 3.8$ & \multirow[t]{3}{*}{41.3} & \multirow[t]{3}{*}{$<0.01$} \\
\hline & & Mean & 20.0 & 11.5 & 8.5 & & \\
\hline & & Min.-max. & $16-25$ & $6-21$ & $0-14$ & & \\
\hline & \multirow{4}{*}{$\begin{array}{l}\text { Group } 2 b \\
(n=13)\end{array}$} & Mean \pm SD & $19.8 \pm 2.8$ & $15.7 \pm 3.0$ & $4.1 \pm 2.7$ & \multirow[t]{3}{*}{20.7} & \multirow[t]{3}{*}{$<0.01$} \\
\hline & & Mean & 20.0 & 16.0 & 4.0 & & \\
\hline & & Min.-max. & $16-24$ & $9-20$ & $0-8$ & & \\
\hline & & & $\begin{array}{l}\text { VAS before } \\
\text { treatment }\end{array}$ & $\begin{array}{l}\text { VAS after } \\
\text { treatment }\end{array}$ & $\begin{array}{l}\text { VAS } \\
\text { difference }\end{array}$ & $\begin{array}{l}\text { VAS decrease } \\
\text { ratio }\end{array}$ & \\
\hline \multirow[t]{6}{*}{ Group 1} & \multirow{3}{*}{$\begin{array}{l}\text { Group 1a } \\
(n=13)\end{array}$} & Mean \pm SD & $79.2 \pm 7.0$ & $48.5 \pm 12.6$ & $30.8 \pm 15.6$ & \multirow[t]{3}{*}{38.1} & \multirow[t]{3}{*}{$<0.01$} \\
\hline & & Mean & 75.0 & 45.0 & 35.0 & & \\
\hline & & Min.-max. & $70-90$ & $35-75$ & $0-55$ & & \\
\hline & \multirow{3}{*}{$\begin{array}{l}\text { Group 1b } \\
(n=13)\end{array}$} & Mean \pm SD & $79.9 \pm 8.1$ & $48.8 \pm 14.4$ & $31.1 \pm 15.9$ & \multirow[t]{3}{*}{38.5} & \multirow[t]{3}{*}{$<0.01$} \\
\hline & & Mean & 80.0 & 45.0 & 35.0 & & \\
\hline & & Min.-max. & $70-95$ & $30-80$ & $0-50$ & & \\
\hline \multirow[t]{6}{*}{ Group 2} & \multirow{3}{*}{$\begin{array}{l}\text { Group 2a } \\
(n=14)\end{array}$} & Mean \pm SD & $78.9 \pm 7.6$ & $49.3 \pm 12.7$ & $29.6 \pm 12.6$ & \multirow[t]{3}{*}{37.4} & \multirow[t]{3}{*}{$<0.01$} \\
\hline & & Mean & 77.5 & 50.0 & 32.5 & & \\
\hline & & Min.-max. & $70-95$ & $30-75$ & $0-50$ & & \\
\hline & \multirow{3}{*}{$\begin{array}{l}\text { Group 2b } \\
(n=13)\end{array}$} & Mean \pm SD & $78.8 \pm 6.2$ & $76.1 \pm 11.2$ & $2.7 \pm 8.6$ & \multirow[t]{3}{*}{3.5} & \multirow[t]{3}{*}{0.27} \\
\hline & & Mean & 80.0 & 80.0 & 0.0 & & \\
\hline & & Min.-max. & $70-90$ & $50-90$ & $(-5)-25$ & & \\
\hline \multicolumn{8}{|c|}{ 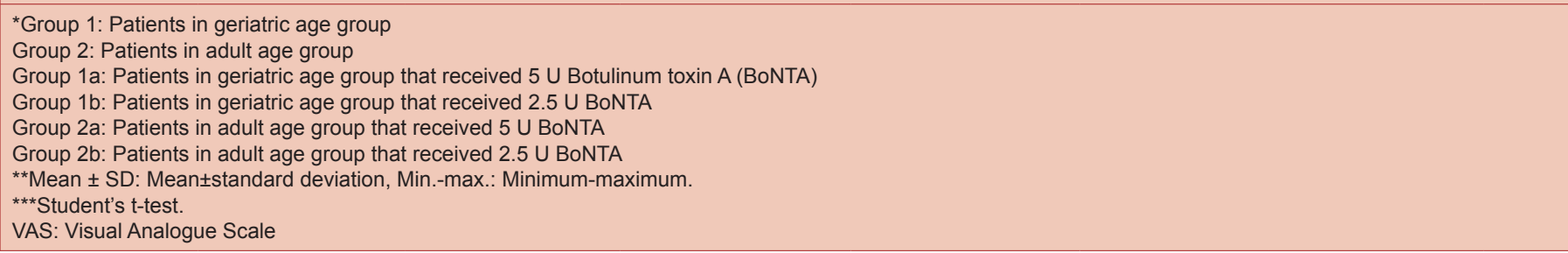 } \\
\hline
\end{tabular}

\section{Discussion}

In this study, three-months of follow-up results were evaluated retrospectively. In this study, the application fields are standard and the results of BoNTA application at $2.5 \mathrm{U}$ and $5 \mathrm{U}$ doses were examined. In the elderly population, BoNTA was administered in $2.5 \mathrm{U}$ and $5 \mathrm{U}$ doses in a single session in $\mathrm{CM}$ patients. These two doses were found to be effective in reducing the number of headache days and the severity of pain in migraine after the treatment compared to the pre-treatment. In the young population, BoNTA was administered in $2.5 \mathrm{U}$ and $5 \mathrm{U}$ doses in a single session in CM patients. Five doses were found to be effective in decreasing the frequency of attacks and the severity of pain in migraine after the treatment compared to the pre-treatment. When the elderly and young population groups were compared, 5 of the results of BoNTA application were found to be similar in both groups. However, $2.5 \mathrm{U}$ of BoNTA application results were found to be more effective in reducing the frequency and severity of attacks in migraine in the elderly population.

BoNTA treatment is a promising treatment for CM. BoNTA is one of the most commonly used methods in CM. The efficacy of BoNTA for migraine and primary headache treatment was found 


\begin{tabular}{|c|c|c|c|c|c|}
\hline & & Groups & Mean & $S^{* *}$ & $\mathbf{p}^{* * *}$ \\
\hline \multirow{8}{*}{$\begin{array}{l}\text { Receiving } \\
5 \mathrm{U} \\
\text { treatment }\end{array}$} & \multirow[t]{2}{*}{ Headache days before treatment } & Group 1* & 19.54 & 3.017 & \\
\hline & & Group 2 & 20.07 & 2.336 & 0.61 \\
\hline & \multirow[t]{2}{*}{ Headache days after treatment } & Group 1 & 11.69 & 3.683 & \\
\hline & & Group 2 & 11.79 & 4.061 & 0.95 \\
\hline & \multirow[t]{2}{*}{ VAS before treatment } & Group 1 & 79.23 & 7.026 & 0.92 \\
\hline & & Group 2 & 78.93 & 7.641 & \\
\hline & \multirow[t]{2}{*}{ VAS after treatment } & Group 1 & 48.46 & 12.647 & 0.87 \\
\hline & & Group 2 & 49.29 & 12.688 & \\
\hline \multirow{8}{*}{$\begin{array}{l}\text { Receiving } \\
2.5 \mathrm{U} \\
\text { treatment }\end{array}$} & \multirow[t]{2}{*}{ Headache days before treatment } & Group 1 & 19.62 & 3.150 & 0.84 \\
\hline & & Group 2 & 19.85 & 2.853 & \\
\hline & \multirow[t]{2}{*}{ Headache days after treatment } & Group 1 & 12.08 & 3.546 & 0.01 \\
\hline & & Group 2 & 15.69 & 3.172 & \\
\hline & \multirow[t]{2}{*}{ VAS before treatment } & Group 1 & 79.92 & 8.067 & 0.70 \\
\hline & & Group 2 & 78.85 & 6.176 & \\
\hline & \multirow[t]{2}{*}{ VAS after treatment } & Group 1 & 48.85 & 14.456 & $<0.01$ \\
\hline & & Group 2 & 76.15 & 11.209 & \\
\hline $\begin{array}{l}\text { * Group 1: Pat } \\
\text { Group 2: Patie } \\
{ }^{*} \text { SD: Standar } \\
{ }^{* *} \text { Student's t- } \\
\text { VAS: Visual Ar }\end{array}$ & $\begin{array}{l}\text { geriatric age } \\
\text { adult age } \\
\text { n. } \\
\text { scale }\end{array}$ & & & & \\
\hline
\end{tabular}

to be different in recent studies. The application techniques and criteria for determining the areas of use are not clear. In recent studies, the importance of BoNTA treatment in many painful conditions such as migraine and primary headache has been emphasized and treatment strategies for head and neck region have been tried to be developed. In a study by Silberstein, 25 $\mathrm{U}$ and $75 \mathrm{U}$ BoNTA were used as a preventive treatment for 123 migraine patients aged 18-65 years. Both $25 \mathrm{U}$ and $75 \mathrm{U}$ BoNTA were found to be effective in treatment. Side effects were more common in patients receiving $75 \mathrm{U}$ BoNTA. BoNTA is an exocytotic inhibitor. Although the mechanism is not fully known, it has been reported to inhibit pain pathways through the sensory system (12).

In clinical trials of PREEMPT (10), BoNTA was found to be effective and reliable in reducing the frequency of headache in the treatment of $\mathrm{CM}$ prophylaxis. Analysis of the data collected from the PREEMPT 1 and 2 clinical studies also showed a positive effect on headache severity. In these studies, $155 \mathrm{U}$ of BoNTAs were applied to 31 points in the head and neck region. In some patients, BoNTA was applied to 39 anatomical sites according to the pain follow-up strategy. Unlike our study, BoNTA applications were performed with certain cycles. Patients were not evaluated according to age factor. In addition, high doses of BoNTA were administered.

In the multicenter open-label COMPEL study (11), a total of $155 \mathrm{U}$ of BoNTAs were applied to 31 fixed points, similar to the
PREEMPT study. 9 sessions were performed every 12 weeks and 108 weeks treatment period data were examined. The aim of this study was to evaluate the long-term efficacy and safety of BoNTA in adults with CM. As a result of the study, it was found that the frequency of headache decreased significantly. After each session, the side effects were evaluated, and it was found that the side effects decreased with increasing number of sessions. In this study, the elderly population was not examined separately. In addition, the efficacy of lower dose BoNTA administration was evaluated so we used different doses and injection sides (not as the same as PREEMPT study) according to our clinic experience.

The present study has some limitations; we evaluated patients retrospectively, which may lead to the possibility of selection bias. The study population was small in four groups, and the follow-up period of the patients in this study was 3 months, and this was a relatively short period.

\section{Conclusion}

As a result of our study, $5 \mathrm{U}$ of BoNTA applications to standard muscles in the treatment of $\mathrm{CM}$ were found to be an effective treatment method in both young and old population. At the end of the study, it was found that treatment efficacy of BoNTA was superior (to the standard muscles) to $2.5 \mathrm{U}$ of application at the younger population. The efficacy of lower doses of BoNTA treatment in $\mathrm{CM}$ was found to be effective in elderly population. 
In addition, no serious side effects were observed during the injections, which would lead to the termination of the study. This demonstrates the safety and tolerability of BoNTA applications in the preventive treatment of $\mathrm{CM}$.

The efficacy of pericranial muscle BoNTA injections for the treatment of CM was found to be different in many studies. These differences may be due to the presence of different types of headache associated with CM may result from factors such as BoNTA dose, pharmacological combination, study design, method of administration, and number of applications. Prospective, randomized, double-blind, placebo-controlled, long-term studies with different doses of BoNTA, by using different head and neck muscles and recurrent injections are needed to fully demonstrate the effectiveness and potency of BoNTA applications in the treatment of CM.

\section{Ethics}

Ethics Committee Approval: This study was approved by the Liv Hospital Local Ethics Committee (protocol no: 2019/002008).

Informed Consent: All patients underwent the procedure after obtaining written informed consent.

Peer-review: Externally peer-reviewed.

Financial Disclosure: The author declared that this study received no financial support.

\section{References}

1. Leonardi M, Raggi A. A narrative review on the burden of migraine: when the burden is the impact on people's life. J Headache Pain. 2019:25;20:41.

2. Arbab MA, Wiklund L, Svendgaard NA. Origin and distribution of cerebral vascular innervation from superior cervical, trigeminal and spinal ganglia investigated with retrograde and anterograde WGA-HRP tracing in the rat. Neuroscience. 1986;19:695-708.

3. Goadsby PJ, Edvinsson L, Ekman R. Release of vasoactive peptides in the extracerebral circulation of humans and the cat during activation of the trigeminovascular system. Ann Neurol. 1988:23:193-196.

4. Sarchielli P, Alberti A, Floridi A, Gallai V. Levels of nerve growth factor in cerebrospinal fluid of chronic daily headache patients. Neurology. 2001;57:132-134.

5. Deen M, Martinelli D, Pijpers J, et al. Adherence to the 2008 IHS guidelines for controlled trials of drugs for the preventive treatment of chronic migraine in adults. Cephalalgia. 2019;39:1058-1066.

6. Karadaş Ö, Özön AÖ, Özçelik F, Özge A. Greater occipital nerve block in the treatment of triptan-overuse headache: A randomized comparative study. Acta Neurol Scand. 2017; 135:426-433.

7. Inan LE, Inan N, Karadaş Ö, Gül HL, Erdemoğlu AK, Türkel Y, Akyol A. Greater occipital nerve blockade for the treatment of chronic migraine: a randomized, multicenter, double-blind, and placebo-controlled study. Acta Neurol Scand. 2015;132:270-277.

8. Gul HL, Ozon AO, Karadas O, Koc G, Inan LE. The efficacy of greater occipital nerve blockade in chronic migraine: A placebo-controlled study. Acta Neurol Scand. 2017;136:138-144.

9. Do TP, Hvedstrup J, Schytz HW. Botulinum toxin: A review of the mode of action in migraine. Acta Neurol Scand. 2018; 137:442-451.

10. Matharu M, Halker R, Pozo-Rosich P, DeGryse R, Manack Adams A, Aurora SK. The impact of onabotulinumtoxinA on severe headache days: PREEMPT 56-week pooled analysis. J Headache Pain. 2017:18:78.

11. Winner PK, Blumenfeld AM, Eross EJ, Orejudos AC, Mirjah DL, Adams AM, Brin MF. Long-Term Safety and Tolerability of OnabotulinumtoxinA Treatment in Patientswith Chronic Migraine: Results of the COMPEL Study. Drug Saf. 2019;42:1013-1024.

12. Silberstein S, Mathew N, Saper J, Jenkins S. Botulinum toxin type $A$ as a migraine preventive treatment. For the BOTOX Migraine Clinical Research Group. Headache. 2000;40:445-450. 